\title{
Clinical significance of thin cytology and HPV DNA test in diagnosing cervical disease
}

\author{
Song Ji Rong ${ }^{1}$, Rajina Shrestha ${ }^{1 *}$, Dipesh Pradhan², Koun Linka' and Jasma Mally ${ }^{3}$ \\ *Correspondence: rajinashrestha76@yahoo.com \\ 'Department of Obstetrics and Gynecology, Jiamusi University, Jiamusi 154007, Heilongjiang PR China. \\ ${ }^{2}$ Norman Bethune College of Medicine, Jilin University, Changchun 130021, China. \\ ${ }^{3}$ Department of Obstetrics and Gynecology, Norman Bethune College of Medicine, Jilin University, Changchun 130021, China.
}

\begin{abstract}
Objectives: To evaluate the sensitivity and accuracy of the HPV DNA test in conjunction with Thinprep cytology test as a screening method of human papillomavirus (HPV) infection.

Method: In our retrospective study, 158 women with age group 21-70 years having positive thin cytology test were recruited. A computerized search identified patients with ASCUS, LSIL, HSIL in Thinprep test results and high risk HPV DNA testing and cervical biopsy results of these patients.

$\underline{\text { Results: }}$ Out of 158 patients, HPV DNA tests were positive in 52 (32.9\%) and negative in 106 (67.1\%). High grade CIN and Carcinoma Cervix were commonly associated with ASCUS and HSIL as CIN I, II-III, III, Carcinoma Cervix, were 53.6\%, 24.3\%, $22.2 \%$ and $15 \%$ respectively for ASCUS $(n=67)$; and $0 \%, 63.2 \%, 77.8 \%, 75 \%$ for HSIL $(n=49)$. HPV DNA positive extremely favors CIN II-III, III and cervical cancer as Human Papilloma Virus DNA test were positive in 22 (78.6\%) out of 28 cases of CIN I, 36 (97.5\%) out of 37 cases of CIN II-III, 9 (100\%) out of 9 cases of CINIII and 4 (100\%) out of 4 cases of cervical cancer. There was significant correlation of TCT with HPV, age and CIN $(\mathrm{P}<0.0001)$. HPV DNA was common in increasing age group as compared to young age (21-30 years, $n=39[46.2 \%]$ vs. $61-70$ years, $n=4[100 \%])$.

Conclusion: Combined thin cytology test along with HR HPV DNA test has great value in determining high grade of cervical intraepithelial neoplasia and cervical neoplasia.

Keywords: Human papilloma virus, cervical intraepithelial neoplasia, squamous intraepithelial neoplasia, atypical squamous cells thin cytology test
\end{abstract}

\section{Introduction}

The concept of preinvasive disease of the cervix was introduced in 1947, when it was recognized that epithelial changes could be identified that had the appearance of invasive cancer but were confined to the epithelium [1]. Subsequent studies showed that these lesions, if left untreated could progress to cervical cancer [2]. Improvements in cytologic assessment led to the identification of early precursor lesions called dysplasia, a name that acknowledges the malignant potential of these lesions. The concept of cervical intraepithelial neoplasia (CIN) was introduced in 1968, when Richart suggested that dysplasias have the potential for progression [3]. The criteria for the diagnosis of intraepithelial neoplasia may vary according to the pathologist but the significant features are cellular immaturity, cellular disorganization, nuclear abnormality, and increased mitotic activity. The extent of the mitotic activity, immature cellular proliferation, and nuclear atypia identifies the degree of neoplasia. If the presence of mitoses and immature cells is limited to the lower third of the epithelium, the lesion usually is designated as CIN1. Involvement of the middle and upper thirds is diagnosed as CIN2 and CIN 3, respectively. CIN most often arises in an area of metaplasia in the transformation zone at the advancing squamocolumnar junction (SCJ). Metaplasia advances from the original SCJ inward, toward the external os and over the columnar villi, to establish the transformation zone. CIN is most likely to begin either during menarche or after pregnancy, when metaplasia is most active; after menopause, metaplasia is less active and a woman has a lower risk of developing $\mathrm{CIN}$.

Untreated, most CIN1 and some CIN 2 lesions spontaneously regress; nevertheless, CIN refers to a lesion that may progress to invasive carcinoma. This term is equivalent to the term dysplasia, which means abnormal maturation; consequently, proliferating metaplasia without atypical mitotic activity should not be called dysplasia. Squamous metaplasia should not be diagnosed as dysplasia or (CIN) because it does not progress to invasive cancer. More than $90 \%$ of CIN is attributed to human papillomavirus (HPV) infection. Only certain types of HPV cause high-grade intraepithelial lesions and cancer (HPV -16,$18,-31,-33,-35,-39,-45,-51,-56,-58,-59,-68)$. Type 16 is the most common form of HPV found in invasive cancer and in CIN 2 and CIN 3; it is found in $47 \%$ of women with cancer. Potentially premalignant squamous lesions fall into three categories: (i) atypical squamous cells (ASC), (ii) low-grade squamous intraepithelial lesions (HSIL). The ASC category is sub-divided into two categories: those of unknown significance (ASC-US) 
Rong et al. Gynecology 2013,

http://www.hoajonline.com/journals/pdf/2052-6210-1-7.pdf

doi: 10.7243/2052-6210-1-7

Table 1. Cervical biopsy results in numbers and percentages in our study.

\begin{tabular}{lcc}
\hline Cervical biopsy & Numbers & Percentage \\
\hline Chronic cervicitis & 80 & $50.6 \%$ \\
CIN I & 28 & $17.7 \%$ \\
CIN II-III & 37 & $23.4 \%$ \\
CIN III & 9 & $5.7 \%$ \\
Cervical cancer & 4 & $2.5 \%$ \\
\hline
\end{tabular}

and those in which high-grade lesions must be excluded (ASC-H). The LSIL category includes CIN I (mild dysplasia) and the changes of HPV, termed koilocytotic atypia. The HSIL category includes CIN 2 and CIN 3 (moderate dysplasia, severe dysplasia, and carcinoma in situ).

The spontaneous regression rate of biopsy-proven CIN1 is $60 \%$ to $85 \%$ in prospective studies. The regressions typically occur within a 2-year follow up with cytology and colposcopy. For LSIL that persists longer than 2 years, the choice of treatment is optional. Expectant management is still appropriate in some patients, and ablative therapies, including cryotherapy and laser ablation are acceptable treatment modalities. When a cytologic specimen suggests the presence of HSIL, colposcopy and directed biopsy should be performed. Although high-grade CIN can be treated with a variety of techniques, the preferred treatment for CIN 2 or 3 in nonadolescent patients is loop electrosurgical excision procedure (LEEP).

\section{Methodology}

To decrease the false-negative rate of cervical cytology, attempts have been made to improve both specimen collection and quality and to reduce errors of interpretation. Over the past several years, several liquid-based techniques have been approved by the Food and Drug Administration in the United States. These techniques differ from the conventional method of Papanicolaou smear collection in several ways. Once the clinician obtains a scraping of the Squamocolumnar junction and transformation zone are of the exocervix the spatula and brush are dipped and agitated in a small bottle of fixative solution to elute the cells rather than being smeared on a glass slide. This bottle is then labeled and sent to the cytology laboratory rather than sending a slide. Once in the lab, a machine prepares a slide containing about 40,000 representative epithelial cells in a thin layer. The slide is viewed by the cytologist and cytopathologist.

The newer second-generation hybrid capture technology uses DNA hybridization and quantification by a chemiluminescence reaction to identify the presence of any of 13 different, high risk HPV subtypes. Indeed, HPV testing was demonstrated to be more sensitive than traditional Pap smear or liquid based cytology in a study by Schiffman and colleagues. The Digene HC2 High-Risk HPV DNA Test is a laboratory test used to show the presence or absence of the genetic (DNA) material from the Human Papilloma virus (HPV), in cells from a cervix. When HPV genetic material is found in these cells, it sometimes indicates the potential or the presence of disease. The cells are obtained by gentle scraping the surface of the cervix. The test causes the release of DNA from the cervical cells: Normal DNA and, if present HPV DNA. Probe molecules are added that combine with the DNA from the cervical cells: normal DNA and, if present, HPV DNA. Probe molecules are added that combine with the DNA to form what is called DNA-Probe-Hybrid. This Hybrid recognizes many types of high-risk HPVs. Then, light-producing antibodies are added and combine with the DNA-Probe-Hybrid. The amount of light produced above a certain level indicates the presence of HPV. Anything below that level indicates either the absence of HPV or HPV-levels that are too low to detect.

Our study includes total 158 patients (age 21-70 years) from two hospitals affiliated under Jiamusi University and Jilin University, China. These patients underwent thin cytology test, HPV DNA test and colposcopy guided biopsy. There is no history of any surgical or medical treatment in the cervix are included in our study. A standard colposcopic examination involves careful inspection of the cervix with both low and high-power magnification after application of normal saline and then $3 \%$ to $5 \%$ acetic acid. After examination with the standard white light, a green filter may be used on the light source to increase the contrast of the red blood vessels and help clarify any vascular changes present. Lugol's iodine solution may also be used to stain the cervix to clarify areas of dysplasia, metaplasia, or columnar epithelium. To evaluate the cervix for abnormal squamous epithelium, all of the squamous epithelium needs to be examined. A careful systematic evalution of the cervix and upper vagina is performed, concentrating on the transformation zone adjacent to the squamocolumnar junction. Areas of white epithelium, punctuation and mosaic are noted. The severity of any lesions seen are graded based on the whiteness of the epithelium, the intercapillary distance in vascular lesions, the sharpness of the lesion border and the surface contour (flat, ulcerated, or raised). The staining characteristics of the lesion with Lugol's iodine also been used to grade CIN. Once a lesion has been identified, the most severely abnormal area or areas are selected, and a colposcopically directed biopsy is done.

\section{Results}

The mean age of our study is $38.28 \pm 10.26$. (Table 1 ) shows cervical biopsy results of this study where the inflammation is 50.6\%, CIN I 17.7\%, CIN II-III 23.4\%, CIN III 5.7\% AND Cervical CA $2.4 \%$. Among 158 patients, ASCUS was seen in 67 (42\%), LSIL in 49(31\%), HSIL in 42(26.6\%). Out of 158 patients, HPV DNA test positive were in 52(32.9\%) and negative in $106(67.1 \%)$. Our study has shown that $41-50$ years age group have little bit higher chance in getting CINIII and Cervical CA as shown in (Table 2). High grade CIN and CA Cx were 
Rong et al. Gynecology 2013,

http://www.hoajonline.com/journals/pdf/2052-6210-1-7.pdf

Table 2. Cervical biopsy results in different age group in our study.

\begin{tabular}{llllll}
\hline $\begin{array}{l}\text { Age group } \\
\text { (Years) }\end{array}$ & $\begin{array}{l}\text { Chronic } \\
\text { cervicitis } \\
(\mathbf{n = 8 0})\end{array}$ & $\begin{array}{l}\text { CIN I } \\
(\mathbf{n}=\mathbf{2 8})\end{array}$ & $\begin{array}{l}\text { CIN II-III } \\
(\mathbf{n}=\mathbf{3 7})\end{array}$ & $\begin{array}{l}\text { CIN III } \\
(\mathbf{n}=\mathbf{9})\end{array}$ & $\begin{array}{l}\text { Cervical } \\
\mathbf{C a} \\
(\mathbf{n = 4})\end{array}$ \\
\hline $21-30(39)$ & $33(41.3 \%)$ & $4(14.3 \%)$ & $1(2.7 \%)$ & $1(11.1 \%)$ & $0(0 \%)$ \\
$31-40(55)$ & $30(37.5 \%)$ & $13(46.4 \%)$ & $10(27 \%)$ & $1(11.1 \%)$ & $1(25 \%)$ \\
$41-50(48)$ & $13(16.3 \%)$ & $9(32.9 \%)$ & $20(54.1 \%)$ & $4(44.4 \%)$ & $2(50 \%)$ \\
$51-60(12)$ & $3(3.8 \%)$ & $1(3.6 \%)$ & $6(16.2 \%)$ & $2(22.2 \%)$ & $0(0 \%)$ \\
$61-70(4)$ & $1(1.3 \%)$ & $1(3.6 \%)$ & $0(0 \%)$ & $1(11.1 \%)$ & $1(25 \%)$ \\
\hline
\end{tabular}

Table 3. Confirmed biopsy results of ASCUS, LSIL and HSIL.

\begin{tabular}{llllll}
\hline $\begin{array}{l}\text { Thin cytology } \\
\text { test } \\
(\mathbf{n}=\mathbf{1 5 8})\end{array}$ & $\begin{array}{l}\text { Chronic } \\
\text { cervicitis } \\
(\mathbf{n}=\mathbf{8 0})\end{array}$ & $\begin{array}{l}\text { CIN I } \\
(\mathbf{n}=\mathbf{2 8})\end{array}$ & $\begin{array}{l}\text { CIN II-III } \\
(\mathbf{n}=\mathbf{3 7})\end{array}$ & $\begin{array}{l}\text { CIN III } \\
(\mathbf{n}=\mathbf{9})\end{array}$ & $\begin{array}{l}\text { Cancer } \\
\text { cervix } \\
(\mathbf{n}=\mathbf{4})\end{array}$ \\
\hline ASCUS (n=67) & $40(50 \%)$ & $15(53.6 \%)$ & $9(24.3 \%)$ & $2(22.2 \%)$ & $1(25 \%)$ \\
LSIL (n=42) & $31(38.8 \%)$ & $13(46.4 \%)$ & $5(13.5 \%)$ & $0(0 \%)$ & $0(0 \%)$ \\
HSIL (49) & $9(11.3 \%)$ & $0(0 \%)$ & $23(63.2 \%)$ & $7(77.8 \%)$ & $3(75 \%)$ \\
\hline
\end{tabular}

Table 4. Patients with HPV DNA test $<1 \mathrm{pg} / \mathrm{ml}$ and $>1 \mathrm{pg} / \mathrm{ml}$ correlated with biopsy results are as follows.

\begin{tabular}{llclll}
\hline $\begin{array}{l}\text { HPV DNA test } \\
(\mathbf{n}=\mathbf{8 0})\end{array}$ & $\begin{array}{l}\text { Chronic } \\
\text { cervicitis } \\
(\mathbf{n}=\mathbf{2 8})\end{array}$ & $\begin{array}{l}\text { CIN I } \\
(\mathbf{n}=\mathbf{3 7})\end{array}$ & $\begin{array}{l}\text { CIN II-III } \\
(\mathbf{n}=\mathbf{9})\end{array}$ & $\begin{array}{l}\text { CIN III } \\
(\mathbf{n}=\mathbf{4})\end{array}$ & $\begin{array}{l}\text { Cervical } \\
\text { cancer }\end{array}$ \\
\hline$<1 \mathrm{pg} / \mathrm{ml}$ & $45(56.3 \%)$ & $6(21.4 \%)$ & $1(2.7 \%)$ & $0(0 \%)$ & $0(0 \%)$ \\
$>1 \mathrm{pg} / \mathrm{ml}$ & $35(43.8 \%)$ & $22(78.6 \%)$ & $36(97.5 \%)$ & $9(100 \%)$ & $4(100 \%)$ \\
\hline
\end{tabular}

Table 5. Correlation between thin cytology test and HPV DNA test, thin cytology test and Age, thin cytology test and cervical intraepithelial neoplasia, HPV DNA test and Age, CIN and HPV, CIN and Age, speculum examination and CIN.

\begin{tabular}{lcc}
\hline Correlation & Coefficient $(\mathbf{r})$ & P-value \\
\hline TCT and HPV & 0.426 & $0.0001^{* * *}$ \\
TCT and Age & 0.420 & $0.0001^{* * *}$ \\
TCT and CIN & 0.420 & $0.0001^{* * *}$ \\
HPV and Age & 0.307 & $0.0001^{* * *}$ \\
CIN and HPV & 0.491 & $0.0001^{* * *}$ \\
CIN and Age & 0.468 & $0.0001^{* * *}$ \\
Speculum exam \& CIN & 0.209 & $0.008^{*}$ \\
\hline
\end{tabular}

P value $<0.05=$ clinically significant ${ }^{*},<0.005=$ very highly significant ${ }^{* *},<0.0005=$ very very highly significant $^{* * *}$

commonly associated with ASCUS and HSIL as CIN I, II-III, III, Ca Cx (Carcinoma of cervix), were $53.6 \%, 24.3 \%, 22.2 \%$ and $15 \%$ respectively for ASCUS ( $n=67)$; and $0 \%, 63.2 \%, 77.8 \%$, $75 \%$ for HSIL ( $n=49)$. For LSIL, CIN I, II-III, III, Ca Cx were $46.4 \%, 13.5 \%, 0 \%$ and $0 \%$ respectively. These finding verify that HSIL and ASCUS are associated with high grade CIN and cervical cancer compared to LSIL as shown in (Table 3). Human papilloma virus DNA test by hybrid capture II for high risk HPV were positive in $36(97.5 \%)$ out of 37 cases of CIN II-III, $9(100 \%)$ out of 9 cases of CINIII and 4 (100\%) out of 4 cases of cervical cancer as shown in (Table 4). These findings suggest that HPV DNA positive extremely favors CIN II-III, III and cervical cancer. In our study HPV-DNA test has sensitivity of $78.57 \%, 97.29 \%, 100 \%$ in CIN I, CIN II-III, CIN III respectively whereas from TCT (ASCUS) has sensitivity of $35.7 \%, 24.32 \%$, $22.2 \%$ in CIN I, CIN II-III, CIN III respectively. Our study has shown absolute correlation between thin cytology test and HPV DNA test, thin cytology test and Age, thin cytology test and CIN, HPV and Age, CIN and HPV, CIN and Age where P values are $<0.0001$ (Table 5).

\section{Discussion}

This study was designed to evaluate the sensitivity and accuracy of the HPV DNA test in conjunction with Thinprep cytology test as a screening method of human papillomavirus (HPV) infection. This study has clearly shown that the sensitivity and accuracy of detecting CIN and cancer is more upgraded when Hybrid capture II DNA test is done in conjunction with thin prep cytology test. HC2 is a second-generation commercial HPV detection test, designed to detect HPV types divided into high-risk and low-risk groups. It has been correlated with detection of HPV DNA sequences by type-specific or consensus PCR in experienced laboratories. Peyton et al., showed more than $90 \%$ agreement between $\mathrm{HC}$-positive results with both Digene Specimen Transport Medium and PreservCyt medium [4]. Moreover, Clavel et al., argued that the HC2 assay is a more convenient and easier test than the PCR assay for routine use [5]. The first-generation assay $(\mathrm{HC})$ had a high rate of false-positive results $(18 \%)$, but the second generation assay $(\mathrm{HC} 2)$ is more accurate and provides better sensitivity [6]. This is due mainly to a reformulation of hybridization reagents and, to a lesser extent, the addition of new HPV probes (types 58 and 68) [7]. Although the HC2 assay is convenient, its reliability depends on critical analysis of the results, as each sample is examined only once and not in duplicate owing to the high cost of the test and in accordance with the manufacturer's instructions. In present study, HR HPV $>1 \mathrm{pg} / \mathrm{ml}$ is significantly positive in CIN II-III $=97.5 \%, \mathrm{CIN} \mathrm{III}=100 \%$ and cervical carcinoma $=100 \%$. High risk HPV is present in all high grade neoplasia. HPV testing is more sensitive than cytology, while cytology is more specific. Several large randomized clinical trials in the past 5 years within national screening programs in Italy, England, Sweden, and the Netherlands examined the value of a primary HPV-based screening strategy [8-11]. These studies confirmed the superior sensitivity of HPV testing for detection of CIN2+. Since, our study is limited to two institutions and limited populations, our results may vary with other studies. The study focuses on the comparative study of the high risk HPV test positive with ASCUS which has shown that, in CIN II-III, 
Rong et al. Gynecology 2013,

http://www.hoajonline.com/journals/pdf/2052-6210-1-7.pdf

doi: 10.7243/2052-6210-1-7

Table 6. HPV prevalence in age group in range ( $n=$ no. of patients).

\begin{tabular}{lllll}
\hline $\begin{array}{l}\text { 21-30 years } \\
(\mathbf{n}=39)\end{array}$ & $\begin{array}{l}\text { 31-40 years } \\
(\mathbf{n}=\mathbf{3 5})\end{array}$ & $\begin{array}{l}\mathbf{4 1 - 5 0} \text { years } \\
(\mathbf{n}=\mathbf{4 8})\end{array}$ & $\begin{array}{l}\mathbf{5 1 - 6 0} \text { years } \\
(\mathbf{n}=\mathbf{1 2})\end{array}$ & $\begin{array}{l}\mathbf{6 1 - 7 0} \text { years } \\
(\mathbf{n}=\mathbf{4})\end{array}$ \\
\hline $\begin{array}{l}\text { HR-HPV }(+) 18 \\
(46.2 \%)\end{array}$ & $36(65.5 \%)$ & $37(77.1 \%)$ & $11(91.7 \%)$ & $4(100 \%)$ \\
\hline
\end{tabular}

HR HPV DNA test has significantly positive $p$ value $(p<0.001)$. Comparison between HPV testing and cytologic testing as screening tests in women age 30 to 69 in a large Canadian randomized trail HPV DNA testing was $94.6 \%$ sensitive in detecting CIN 2 or CIN 3, compared with 55.4\% for cytology [12]. The HPV- FOCAL trial is comparing HPV then cytology testing vs cytology, then (in women with ASCUS) -HPV then testing [13]. In present study HPV-DNA test has sensitivity of 78.57\%, 97.29\%, 100\% in CIN I, CIN II-III, CIN III respectively whereas from TCT (ASCUS) has sensitivity of $35.7 \%, 24.32 \%$, $22.2 \%$ in CIN I, CIN II-III, CIN III respectively. With the latest evidence based screening guidelines, we can implement a more sensitive and effective screening strategy for better prevention and early detection of cervical cancer. Transient infections are much more common in younger women and are not always of clinical significance in women younger than 30 years [14]. In our series, there was a trend toward an increased incidence of high risk HPV infection in women $31-40$ years age group which accounts $65.5 \%$ and in $41-50$ years age group which accounts $77.1 \%$ (Table 6). Since our study has limited population, we cannot take it as absolute. We cannot evaluate the incidence of transient HPV infection, as no follow up of our population was performed. Woodman et al., in a follow up study of a cohort comprising 1,075 very young female (age 18 years) who had normal and HPV-DNA negative results at presentation, shown that the period during which the virus can be detected sequentially usually is short [15]. This cannot be generalized to larger population, but these very young females had a high incidence of HPV DNA positivity because they are more likely to have HPV infection; however they less frequently develop severe disease. Transient $\mathrm{HPV}$ infection, as frequently observed in very young women, cannot be analyzed by single testing. After 1 year repeated testing should be done, especially for young women with HPV DNA-positive and cytology-negative results, to avoid falsepositive results [14]. The $\mathrm{HC} 2$ assay is a sensitive test to detect HPV-DNA sequences in experimental laboratories; however its use as the only primary test for large - scale screening of cervical cancer should not be advocated.

\section{Conclusion}

$\mathrm{CIN}$ and cervical cancer is common in increasing age group compared to younger age. TCT with ASCUS and HSIL is associated with high grade CIN and cervical neoplasia. HPV DNA positive (>1 pg/ml) is strongly associated with $\mathrm{CIN}$ and cervical cancer. Combined HPV and TCT are very effective in diagnosing high grade $\mathrm{CIN}$ and cervical cancer which later confirmed by cervical biopsy. Further studies are needed with more patients included, and stronger statistically significant differences.

\section{Competing interests}

The authors declare that they have no competing interests.

Authors' contributions

\begin{tabular}{|l|c|c|c|c|c|}
\hline Authors' contributions & RS & SJR & DP & KL & JM \\
\hline Research concept and design & $\checkmark$ & $\checkmark$ & -- & -- & $\checkmark$ \\
\hline Collection and/or assembly of data & $\checkmark$ & -- & -- & $\checkmark$ & $\checkmark$ \\
\hline Data analysis and interpretation & $\checkmark$ & -- & -- & -- & -- \\
\hline Writing the article & $\checkmark$ & -- & -- & -- & -- \\
\hline Critical revision of the article & $\checkmark$ & -- & $\checkmark$ & -- & -- \\
\hline Final approval of article & $\checkmark$ & -- & $\checkmark$ & -- & -- \\
\hline Statistical analysis & $\checkmark$ & -- & -- & -- & -- \\
\hline
\end{tabular}

Acknowledgement

Rajina Shrestha would like to thank tutor Prof. Song Ji Rong for valuable opinion on this manuscript. I would like to thank my husband Dr. Dipesh Pradhan for support, opinion as well as editing in this manuscript.

\section{Publication history}

Editor: Stavros Sifakis, University Hospital of Heraklion, Greece. EIC: Christos lavazzo, Royal Surrey County Hospital, UK.

Received:22-Jul-2013 Revised:19-Sep-2013

Accepted:10-Oct-2013 Published: 30-Oct-2013

\section{References}

1. Pund ER and Nieburgs HE. Preinvasive carcinoma of the cervix uteri; seven cases in which it was detected by examination of routine endocervical smears. Arch Pathol (Chic). 1947; 44:571-7. I PubMed

2. Koss LG, Stewart F, Foote FW, Jordan MJ, Bader GM and Day E. Some Histological Aspects of Behavior of Epidermoid Carcinoma in Situ and Related Lesions of the Uterine Cervix. A Long-Term Prospective Study. Cancer. 1963; 16:1160-211. | Article | PubMed

3. Richart RM. Natural history of cervical intraepithelial neoplasia. Clin Obstet Gynecol 1968; 10:748.

4. Peyton CL, Schiffman M, Lorincz AT, Hunt WC, Mielzynska I, Bratti C, Eaton S, Hildesheim A, Morera LA, Rodriguez AC, Herrero R, Sherman ME and Wheeler CM. Comparison of PCR- and hybrid capture-based human papillomavirus detection systems using multiple cervical specimen collection strategies. J Clin Microbiol. 1998; 36:3248-54. | Article | PubMed Abstract I PubMed Full Text

5. Clavel C, Masure M, Putaud I, Thomas K, Bory JP, Gabriel R, Quereux $C$ and Birembaut $P$. Hybrid capture II, a new sensitive test for human papillomavirus detection. Comparison with hybrid capture I and PCR results in cervical lesions. J Clin Pathol. 1998; 51:737-40. | Article | PubMed Abstract I PubMed Full Text

6. Cuzick J. Screening for cancer: future potential. Eur J Cancer. 1999; 35:1925-32. | Article | PubMed

7. Poljak M, Brencic A, Seme K, Vince A and Marin IJ. Comparative evaluation of first- and second-generation digene hybrid capture assays for detection of human papillomaviruses associated with high or intermediate risk for cervical cancer. J Clin Microbiol. 1999; 37:796-7. I Article | PubMed Abstract | PubMed Full Text

8. Naucler P, Ryd W, Tornberg S, Strand A, Wadell G, Elfgren K, Radberg T, Strander B, Johansson B, Forslund O, Hansson BG, Rylander E and Dillner J. Human papillomavirus and Papanicolaou tests to screen for cervical cancer. N Engl J Med. 2007; 357:1589-97. | Article | PubMed 
Rong et al. Gynecology 2013,

http://www.hoajonline.com/journals/pdf/2052-6210-1-7.pdf

9. Bulkmans NW, Berkhof J, Rozendaal L, van Kemenade FJ, Boeke AJ, Bulk $\mathrm{S}$, Voorhorst FJ, Verheijen RH, van Groningen K, Boon ME, Ruitinga W, van Ballegooijen M, Snijders PJ and Meijer CJ. Human papillomavirus DNA testing for the detection of cervical intraepithelial neoplasia grade 3 and cancer: 5-year follow-up of a randomised controlled implementation trial. Lancet. 2007; 370:1764-72. | Article | PubMed

10. Ronco G, Giorgi-Rossi P, Carozzi F, Confortini M, Dalla Palma P, Del Mistro A, Ghiringhello B, Girlando S, Gillio-Tos A, De Marco L, Naldoni C, Pierotti P, Rizzolo R, Schincaglia P, Zorzi M, Zappa M, Segnan N and Cuzick J. Efficacy of human papillomavirus testing for the detection of invasive cervical cancers and cervical intraepithelial neoplasia: a randomised controlled trial. Lancet Oncol. 2010; 11:249-57. | Article | PubMed

11. Kitchener HC, Almonte $M$, Thomson $C$, Wheeler $P$, Sargent $A$, Stoykova B, Gilham C, Baysson H, Roberts C, Dowie R, Desai M, Mather J, Bailey A, Turner A, Moss $S$ and Peto J. HPV testing in combination with liquidbased cytology in primary cervical screening (ARTISTIC): a randomised controlled trial. Lancet Oncol. 2009; 10:672-82. | Article | PubMed

12. Mayrand MH, Duarte-Franco E, Rodrigues I, Walter SD, Hanley J, Ferenczy A, Ratnam S, Coutlee F and Franco EL. Human papillomavirus DNA versus Papanicolaou screening tests for cervical cancer. $N$ Engl J Med. 2007; 357:1579-88. | Article | PubMed

13. Ogilvie GS, van Niekerk DJ, Krajden M, Martin RE, Ehlen TG, Ceballos K, Peacock SJ, Smith LW, Kan L, Cook DA, Mei W, Stuart GC, Franco EL and Coldman AJ. A randomized controlled trial of Human Papillomavirus (HPV) testing for cervical cancer screening: trial design and preliminary results (HPV FOCAL Trial). BMC Cancer. 2010; 10:111. | Article | PubMed Abstract | PubMed Full Text

14. Woodman CB, Collins S, Winter H, Bailey A, Ellis J, Prior P, Yates $M$, Rollason TP and Young LS. Natural history of cervical human papillomavirus infection in young women: a longitudinal cohort study. Lancet. 2001; 357:1831-6. | Article | PubMed

15. Peyton CL, Schiffman M, Lorincz AT, Hunt WC, Mielzynska I, Bratti C, Eaton S, Hildesheim A, Morera LA, Rodriguez AC, Herrero R, Sherman ME and Wheeler CM. Comparison of PCR- and hybrid capture-based human papillomavirus detection systems using multiple cervical specimen collection strategies. J Clin Microbiol. 1998; 36:3248-54. | Article | PubMed Abstract | PubMed Full Text

\section{Citation:}

Rong SJ, Shrestha R, Pradhan D, Linka K and Mally J. Clinical significance of thin cytology and HPV DNA test in diagnosing cervical disease. Gynecol. 2013; $1: 7$.

http://dx.doi.org/10.7243/2052-6210-1-7 